\title{
TA' AWUN BEHAVIOR, WORK STRESS, WORKLIFE BALANCE IN ISLAMIC PERSPECTIVE AND EMPLOYEE PERFORMANCE : INVESTIGATION IN INDONESIA
}

Muafi MUAFI ${ }^{1 *}$

\begin{abstract}
Received: September 2021 | Accepted: November 2021 | Published: December 2021
Please cite this paper as: Muafi, M. (2021) Ta' awun behavior, work stress, worklife balance in Islamic perspective and employee performance: investigation in Indonesia, Holistica Journal of Business and Public Administration, Vol. 12, Iss. 3, pp.86-100
\end{abstract}

\begin{abstract}
$\mathrm{Ta}^{\prime}$ awun behavior is very rarely being studied in business research especially when associated with employee performance. This study examines and analyzes the partial effect of: (1) ta' awun behavior on employee performance, work stress, and work-life balance in Islamic perspective (WLBIP), (2) work stress and WLBIP on employee performance and (3) the mediating role of work stress and WLBIP in the relationship between ta' awun behavior on employee performance. Data is collected through distributing questionnaires to employees of financial services companies in the Special Region of Yogyakarta with purposive manner. The statistical technique uses Partial Least Square. The results prove that $t \mathrm{a}^{\prime}$ awun behavior is partially able to make a positive contribution to the employees performance and WLBIP. Ta' awun behavior also reduces work stress. Employee work stress reduces employee performance and WLBIP improves employee performance. Work stress is able to mediate ta' awun behavior on employee performance, but WLBIP is not able to mediate it. This study implies that the research model can be applied to employees of business companies, which so far have focused on social and community institutions.
\end{abstract}

Keywords: ta' awun behavior, work stress, WLBIP, employee performance

\section{INTRODUCTION}

Luthans (2002) and Luthans \& Youssef (2007a; 2007b) have introduced and developed the concept of Positive Organizational Behavior (POB) as a concept that realizing everyone has potential and capacity that can be measured, developed, managed. It also

\footnotetext{
${ }^{1}$ Department of Management, Business and Economic Faculty, Universitas Islam Indonesia, Indonesia,muafi@uii.ac.id

*Corresponding author
} 
have an impact on improving their performance. POB originated from the positive organizational scholarship movement pioneered by Cameron \& Caza (2004; Cameron, et al., 2003) which emphasizes more on macro aspects. Furthermore, the next movement is more directed to the micro aspect, which is known as POB (Luthans, 2002). Both of them move from negative behavior which is oriented with dysfunctional behavior to positive behavior which is oriented with functional behavior (Csikszentmihalyi \& Seligman, 2000).

POB can be actualized in outcomes such as: optimism behavior, happiness, forgiveness, psychological capital, and altruism. Likewise, POB in the workplace is usually stated in: hope, optimism, and resilience (Youssef \& Luthans, 2007).

All of them are directed at achieving individual performance (Luthans, et al., 2007; Luthans \& Youssef, 2007a; 2007b), which also have an impact on work satisfaction, work happiness, and organizational commitment (Youssef \& Luthans, 2007). Positive behavior has been shown to have an effect on performance (Luthans, 2002; Youssef \& Luthans, 2007).

This study examines the positive behavior in the Islamic perspective, namely ta' awun behavior and its impact on work stress, work-life balance in Islamic perspective (WLBIP), and employee performance. In Islam, it is very necessary for a person to have positive and constructive behavior. Muslims are people who are assigned to have positive attitudes and behavior because Islam greatly glorifies human status and existence (Aji, 2015). Humans are the most perfect creatures created by Allah SWT compared to other creatures. Allah SWT has given human a mind that is not given to other creatures. Humans who are created by Allah SWT has a purpose (Surah AI Mu'minun, 23: 15). Allah SWT creates the heavens and the earth not without purpose. Allah SWT creates the earth and its contents so that humans are able to manage and carry out the mandate given to them. Humans are created to help each other and are forbidden to complain. A successful human being is one who can use his time for productive and beneficial activities for the large community and not only for the benefit of himself and his family (rahmatan lil 'alamin). Therefore, it is necessary to have the behavior of helping each other between humans. Studies on integrated positive organizational behavior In Islamic Perspective (POBIP) which is associated with work stress, WLBIP, and employee performance areas limited in Asia especially in Indonesia. This study is conducted to fill research gaps and at the same time create novelties, including:

1. Positive organizational behavior in Islamic Perspective (POBIP) is studied by considering the ta' awun (helpful) behavior variable (Astuti, et al., 2020; Rosyidi, 2015) which will be associated with work stress and work-life balance in Islamic perspective (WLBIP) (Muafi, 2021a; 2021b; Muafi et al., 2021) and employee performance

2. There are still inconsistencies in study results related to the antecedents and POB consequences which using western approach, such as performance, work 
satisfaction, organizational commitment (Mardiah, 2019; Kadiyono, 2011; Luthans, 2002; Luthans \& Youssef, 2007a; 2007b; Ramlall, 2008), work engagement (Karetepe et al., 2018; Schmitt et al., 2015; Thompson, 2013), and happiness (Ramlall, 2008), as well as work life balance/WLB (Jaharuddin \& Zainol, 2019; Isse et al. , 2018).

This study is conducted on employees who work in Islamic financial service companies in the Special Region of Yogyakarta (DIY), Indonesia. Employees who work in Islamic financial service companies are required to have positive organizational behavior (Ta' Awun Behavior-TB) in order to reduce work stress and improve Work Life Balance in Islamic Perspectives (WLBIP) so that it is expected to improve their performance.

\section{LITERATURE REVIEW}

\subsection{Ta' Awun Behavior}

Positive organizational behavior (POB) is a behavior that comes from the implementation of the human resources strength in building strength in work. POB also studies a person's psychological state that is formed and measured through company interventions aimed at improving or enhancing employee performance (Luthan, 2002; Luthans \& Youssef, 2007a; 2007b). In the POB there are elements of employee empowerment, positive communication, and support from colleagues (Luthans, 2002). A positive approach is preferred so that $\mathrm{POB}$ is developed by new various concepts and constructs, such as: hope, optimism, altruism, politeness, forgiveness, and engagement (Luthans, 2002; Luthans \& Youssef, 2007a; 2007b).

A focus of this POB study is on ta' awun behavior. In Islam, humans have the main duties and responsibilities as caliphs in the world. Humans are created by Allah SWT to be useful for other people and large society (Q.S. Al Ahzab, 3: 46). Human existence in the world is very noble, namely: (a) individual glory (karâmah fardiyyah) i.e. humans must maintain the outer and inner glory of each individual, (b) community glory (karâmah ijtima`iyyah), as social beings, humans interact between fellow humans, and (c) political glory (karâmah siyâsiyyah), namely humans have political rights to choose or be elected because humans are caliphs on earth (Aji, 2015). Actually, Positive Organizational Behavior in Islamic Perspective (POBIP) can be studied by considering several behaviors, including; ta' awun (like to help), as-sholeh (good and beneficial), Al Itqan (stable personality), Al Ihsan (doing good), and Al mujahadah (hard and optimal work) (Astuti, et al., 2020). This study more focuses on ta' awun behavior because Muslims are required to help each other in goodness without ever caring about religion, race, culture, and others, especially with Muslims. Humans have an obligation to help each other when their friends are in trouble, participate in mutual cooperation in society, and are active in helping other positive activities. 
HOLISTICA Vol 12, Issue3, 2021, pp.86-100

"Cooperate with one another in goodness and righteousness, and do not cooperate in sin and transgression. And be mindful of Allah. Surely Allah is severe in punishment." (AlMaidah: 2)

"Whoever relieves a believer from one trouble in this world, Allah will relieve him from one difficulty on the Day of Resurrection. Whoever relieves a person's suffering, Allah will relieve his suffering in this world and the hereafter. Whoever covers the ugliness of a Muslim, Allah will cover his disgrace in this world and the hereafter. Allah will help a servant as long as the servant is willing to help his brother." (Hadith of Muslim from Abu Hurairah: 4867).

\subsection{HYPOTHESIS DEVELOPMENT}

\section{Ta' awun Behavior and Employee Performance}

Ta' awun behavior in Islam is the behavior of helping each other. The existence of togetherness, mutual belonging, and mutual need of one another. The impact is expected to improve performance and harmonization between one another (Balad, 2019; Rosyidi, 2015). When someone conducts ta' awun behavior, he or she should not only think about business profits or material benefits (Balad, 2019). Employees who have ta' awun behavior tend to have a high social and togetherness spirit, soft heart, avoid hostility, prioritize brotherhood, do not expect anything in return for helping others in need and sincere in charity (Risaldy, 2019; Rosyidi, 2009). , 2015; Qomaro \& Oktasari, 2018). Ta' awun has stages, among others: a) help with knowledge or with wealth b) saying pleasant sentences to friends in a condition (Risaldy, 2019).

The ta' awun concept or help in goodness if the western approach is part of the OCB (altruism) indicator. Kamil et al. (2015; 2014; Kamil \& Ahmad, 2014) have succeeded in developing the OCB concept in an Islamic perspective known as OCBIP which consists of four factors, namely: altruism, civic virtue, advocating high moral standards (Dakwah), and harm removal. OCB from an Islamic perspective encourages employees to do extra work more than what they have to do with an employment contract. In general, employees who are Muslim are more motivated to demonstrate OCB based on Islamic teachings and principles.

Sani \& Ekowati (2019) examine OCBIP behavior associated with service performance. The findings show that the OCBIP of employees who work at the BRI Syariah branch office in Malang has an effect on employee performance. Higher OCBIP will result in better performance, and conversely, lower OCBIP will result in worse performance. Someone who has good outward behavior in Islam will usually reflect the goodness of his internal behavior. The embodiment of goodness in internal behavior is belief in Allah SWT. Islam commands its followers to do to the best of their ability in accomplishing tasks at work. In addition, employees are required to cooperate with their co-workers and help each other in the workplace based on sincerity (Marfuatun \& Muafi, 2020). Wasitowati \& Sudarti (2019) also prove that employees who have ta' awun behavior are 
able to improve their service performance. Each employee will complement and help each other without being asked because it is done only for seeking the Allah SWT's pleasure. They understand that work is worship, so material compensation is not the main goal.

H1. Ta' awun behavior has positive effect on employee performance

\section{Ta' awun Behavior, Work Stress, WLBIP and Employee Performance}

The several studies with western approach conclude that altruism has an effect on work stress. Increasing employee altruism behavior will further reduce employee work stress. Women tend to have higher altruistic behavior than men. People tend to exhibit more altruistic behavioral movements while expressing stress in their lives. It is done to reduce the impact of negative emotions. Pro-social behavior such as empathy and altruism can actually reduce work stress (Shelly \& Narang, 2000). Sparrow et al. (2018) confirm that physiological stress reactivity is a determining factor for altruistic decision making in a person. A person with a higher stress reactivity makes a more generous choice. Older adults have altruism that is not associated with stress reactivity compared to younger adults (Sparrow et al., 2018). Feng et al. (2020) also find that individuals with high altruism show more negative effects on anxiety and depressive symptoms. Post (2008) also concludes that altruism is closely related to better well-being, health, and longevity. There is a strong correlation between well-being, happiness, health, and longevity in emotionally and behaviorally compassionate people.

In Islam the altruism behavior is identical to the ta'awun behavior. Septania \& Khairani (2020) show that there are five main themes in the ta' awun behavior of young Muhammadiyah volunteers in Indonesia, namely: (1) attention to others; (2) helping others; (3) consider others; (4) positive achievements; and (5) positive consequences. The character in the ta' awun behavior of Muhammadiyah young volunteers moves as a rovers to success in mobilizing young volunteers to provide useful values completely in the process of helping survivors. This behavior is expected to reduce employee work stress. Hijrati (2020) concludes that ta' awun behavior can be used in Islamic counseling to help someone achieve a happy and stress-free life.

\section{Q.S. Al Imran: 104}

"And let there be (arising) from you a nation inviting to (all that is) good, enjoining what is right and forbidding what is wrong, and those will be the successful."

H2. Ta' awun behavior has negative effect on employee work stress

Work stress and employee performance 
Every employee is faced with various working situations and conditions. Employees who have a bad work environment and support from coworkers will also experience high work stress. Likewise, a large workload will also increase work stress and reduce employee performance. A person who experiences stress at work usually will not be able to complete his work properly and correctly. Gibson et al (1996) state that work stress is conceptualized stress as: a stimulus, a response, and stimulus-response. While Luthans (2006) defines stress as a response in adjust oneself and influenced by individual differences and psychological processes, consequences of environmental actions, situations, or events that exist. When an employee assumes that the work stress source (stressors) they face can increase positive self-development (challenge stressors), it could improve one's performance. Conversely, when the work stress source experienced is considered an obstacle and has a negative impact (hinderance stressors), it could reduce employee performance (Cavanaugh et al., 2000). Pandey (2020; Ajayi, 2018; Mohsan, et al., 2011; Wu, 2011) state that work stress has a negative and significant effect on employee performance. Negative work stress causes a decrease in employee performance.

\section{H3. Work stress has negative effect on employee performance}

\section{Ta' awun Behavior, Worklife Balance In Islamic perspective (WLBIP), and Employee Performance}

Najmiah (2021) proves that there is a positive correlation between ta' awun behavior and life balance. Humans are created by Allah SWT to live in balance between this world and the hereafter. Humans work to find happiness and safety in this world and the hereafter. Matandra et al. (2020) also conclude that ta' awun behavior requires the role of the government, community leaders, and religious leaders who are useful in terms of policy, education, and socialization to help someone who is less able to have a prosperous and balanced life both physically and mentally.

Muafi (2021a; 2021b) says that in Islam the life balance concept must provide a balance between the world and the hereafter. Employees need to work hard, smart, and be tenacious as if they live forever, but employees also have to think about the afterlife as if death will soon pick them up. Therefore, besides the work orientation that is get salary and other compensation, employees at work must also be serious and sincere because all actions in the world will be accounted for in the hereafter. Actually, the WLBIP concept started with the WLB concept which is recommended to be oriented towards life in this world and the hereafter. So employees are expected to not only have worklife balance in the world but also need to think about the afterlife. When working in the world, employees have to balance not only in work and non-work but also must be oriented to the afterlife. So employees work to have a balance of work and non-work life and still considering the pleasure and reward of Allah SWT and not solely oriented to happiness in the world. Therefore, the Work Life Balance in Islamic Perspective (WLBIP) concept is introduced and developed. Muafi (2021a; 2021b; Muafi et al., 2021) 
succeeded in studying WLBIP by considering three indicators; (1) Time balance in Islamic perspective)/TBIP, (2) involvement balance in Islamic perspective)/IBIP, and (3) Satisfaction balance in Islamic perspective)/SBIP. On the other hand, Kim (2017) proves that WLB positively affects employee performance. The higher the WLB owned by the employee, the higher the employee's performance. This result is supported by Tamunomiebi \& Oyibo (2020) which state that employees who have a balanced WLB between work and non-work life tend to have higher performance compared to employees who do not. However, in measuring service performance Muafi et al. (2021) find that WLBIP has no effect on service performance.

H4. $T a^{\prime}$ awun behavior has positive effect on WLBIP

H5. WLBIP has positive effect on employee performance.

H6. Work stress mediates Ta' awun behavior on employee performance

H7. WLBIP mediates Ta' awun behavior on employee performance

\section{RESEARCH METHOD}

This study uses survey method with a population of all employees of financial service companies in the the Special Region Province of Yogyakarta (DIY). The target sample in this study is 150 employees. This has fulfilled survey study's requirement (Hair et al., 2014). The sampling technique is non-probability sampling with purposive sampling. The selected employee criteria are; (1) Muslim, (2) has worked for at least 3 years, (3) has a minimum education of high school. Data is collected by giving a questionnaire. After all the questionnaires are collected, they are checked. There are 101 quetionnaire who are fulfilled the criteria so that they can be processed further. This study uses four variables; ta' awun behavior, work stress, WLBIP, and employee performance. The measurement of the variables used a Likert Scale with an interval score of 1-5 ranging from a score of 1 (strongly disagree) to a score of 5 (strongly agree). The results of the validity and reliability test conclude that all questionnaire items are valid and the variables are reliable. Furthermore, hypothesis testing using structural equation modeling with Partial Least Square (PLS) technique. The sources of the questionnaires refer to;

1. Ta' awun behavior (TB) consists of 5 items. Source items are adopted from Wasitowati \& Sudarti (2019).

2. Worklife Balance in Islamic perspective (WLBIP) consists of 30 items. Source items are adopted from Muafi (2021a; 2021b) which consist of 3 indicators; (a) Time balance in Islamic Perspectives (TBIP), 7 items; (b) Involvement balance in Islamic perspective/IBIP, 7 items and (3) Satisfaction balance in Islamic perspective)/SBIP. SBIP has 4 indicators; (1) balance in spiritual work satisfaction, 4 items, (2) balance in intellectual work satisfaction, 4 items, (3) 
balance in social work satisfaction, 4 items and (4) balance in material work satisfaction, 4 items.

3. Work stress (WS) consists of 6 items. Source items are adopted and developed from Prasanti (2014; Kessler, 1979; Kessler et al., 2002).

4. Employee Performance (EP) consists of 5 items. Source items are adopted and developed from Chen \& Wei (2020; Irawanto et al., 2015).

\section{RESULT AND DISCUSSION}

\subsection{Respondent Description}

The majority of respondents in this study are male (51\%), age $21-45$ (72\%), bachelor degree $(75 \%)$, has been working for $>3$ years $(65 \%)$, and has income of > IDR 3.5 million per month (85\%).

\subsection{Direct Effect Test}

Furthermore, the Partial Least Square technique is used to test the hypothesis proposed. The testing results of the relationship between variables can be seen in Table 1.

Table 1. Mean, STDEV, T-Values, P-Values

\begin{tabular}{|c|c|c|c|c|c|}
\hline & $\begin{array}{c}\text { Original } \\
\text { Sampel } \\
\text { (0) }\end{array}$ & $\begin{array}{l}\text { Standard } \\
\text { Deviation } \\
\text { (STDEV) }\end{array}$ & $\begin{array}{c}\text { T Statistics } \\
\text { (|O/STDEV|) }\end{array}$ & $\begin{array}{c}\mathbf{P} \\
\text { Values }\end{array}$ & Description \\
\hline TB -> EP & 0,320 & 0,138 & 2,323 & $0,021^{*}$ & H1. Accepted \\
\hline TB $->$ WS & $-0,415$ & 0,148 & 2,797 & $0,005^{*}$ & H2. Accepted \\
\hline WS -> EP & $-0,319$ & 0,116 & 2,757 & $0,006^{*}$ & H3. Accepted \\
\hline TB -> WLBIP & 0,391 & 0,117 & 3,327 & $0,001^{*}$ & H4. Accepted \\
\hline WLBIP $\rightarrow$ EP & 0,219 & 0,109 & 2,005 & $0,046 *$ & H5. Accepted \\
\hline
\end{tabular}

Note: $*$ sign = significant $<\alpha 0.05$

Source: Authors' computation and results, 2021.

Based on the results of hypothesis testing in Table 1, it can be concluded that hypotheses 1 to 5 proposed in this study are accepted.

\subsection{Indirect Effect Test}

Furthermore, it can be seen in Table 2 to test hypotheses 6 and 7. 
Table 2. Original Sampel, STDEV, T-Values, P-Values

\begin{tabular}{lccccc}
\hline & $\begin{array}{c}\text { Original } \\
\text { Sampel } \\
\text { (O) }\end{array}$ & $\begin{array}{c}\text { Standard } \\
\text { Deviation } \\
\text { (STDEV) }\end{array}$ & $\begin{array}{c}\text { T Statistics } \\
(\mid \text { O } / \text { STDEV|) }\end{array}$ & $\begin{array}{c}\text { P } \\
\text { Values }\end{array}$ & Description \\
\hline TB -> WS -> EP & 0,132 & 0,065 & 2,051 & $0,041^{*}$ & H6. Accepted \\
TB -> WLBIP -> EP & 0,086 & 0,053 & 1,599 & 0,110 & H7. Rejected \\
\hline
\end{tabular}

Note: ${ }^{*}$ sign $=$ significant $<\alpha 0.05$

Source: Authors' computation and results, 2021.

Based on the results of hypothesis testing in Table 2, it can be seen that;

(1) Work stress (WS) mediates the effect of ta' awun behavior (TB) on employee performance (EP) so that $\mathbf{H} \mathbf{6}$ is accepted.

(2) WLBIP do not mediate the effect of ta' awun behavior (TB) on employee performance (EP) so that $\mathbf{H} \mathbf{7}$ is rejected.

\section{DISCUSSION AND IMPLICATION}

The results prove that ta' awun behavior can improve employee performance ( $\mathbf{H} \mathbf{1}$ is accepted). This results support Wasitowati \& Sudarti (2019; Balad, 2019; Risaldy, 2019; Qomaro \& Oktasari, 2018; Rosyidi, 2015) that mutual help behavior can improve employee performance. It turns out that ta' awun behavior can be applied to employees who work at Islamic financial services companies. They feel more capable of completing work on time according to their respective workloads. In fact they never neglect the work assigned to him. If this condition occurs, it is possible to harmonize the work environment and make it more comfortable, calm, and safe at work. All employees feel sincere when working even though they still hope for adequate compensation and blessings. Fellow employees can help each other when co-workers experience difficulties both in work and life outside of work. Ta' awun behavior can be realized in addition to providing knowledge or wealth. It can also be done by giving words or sentences that make co-workers happy, comfortable, and calm.

The results also prove that ta' awun behavior increases WLBIP (H4 is accepted). Ta' awun behavior from employees can tend to foster high togetherness as co-workers and as fellow human beings. This condition turned out to be able to encourage employees to have a balance in work and non-work (channeling hobbies, social life, and other nonwork activities). Finally, fellow employees do not envy, hostile, all are brothers, and sincere when helping. This also proves Najmiah (2021; Matandra et al., 2020) which generally confirms that there is a link between ta'awun behavior and the balance of one's life. When employees work, they begin to realize the importance of balancing it 
with non-work life. In WLBIP, employees must have a balance between work and nonwork which must be oriented to the life of the world and the hereafter. Employees must have an Islamic balance of time, engagement, and work satisfaction. This means that time is used by working optimistically, on time, never late, never complaining, and sincerely. Employees must have total work involvement, love their work with all their heart, compete with achievements, and consistent with truth. Likewise, you should be very grateful, satisfied with your work, satisfied with acquiring, sharing new knowledge with your co-workers, satisfied with associating, and interacting with co-workers who are considered as brothers, and trying to get a good salary and compensation. All of them are intended because they want to get the pleasure of Allah SWT. In encouraging ta'awun behavior, companies need to conduct training and development of potential employees both intellectually and spiritually. Emphasis on the spiritual aspect is an important aspect and can be done by providing regular spiritual studies to employees according to their religion and beliefs. Based on the study results, it is also found that WLBIP improves employee performance (H5 is accepted). It is at the same time rejects Muafi et al. (2021) and strengthen Rosyidi (2015; Balad, 2019). Kim (2017) turns out that WLB can positively improve employee performance. Tamunomiebi \& Oyibo (2020) also strengthens the finding that employees who have WLB that are balanced between work and non-work life tend to have increased performance.

Another finding that is no less interesting is that ta'awun behavior reduces employee work stress (H2 is accepted). Employees who experience high stress are usually influenced by psychological conditions and excessive workloads in their work environment (Bailey et al., 2017; Hill et.al., 2001). Therefore, one must be able to balance workload, emotions, and moods as well as time pressure (Hill et.al., 2001; Drapeau, et. al., 2012; Reddy, et.al., 2010). When employees experience high stress, they really need help and assistance from their co-workers. Employees will feel less burdened when there are co-workers who sincerely help them without expecting anything in return, both material and non-material. Shelly \& Narang (2000) also recommend that when employees have a high sense of empathy and altruism, it can reduce work stress. Sparrow et al. (2018) also recommend that someone who is stressed should be able to train to be more generous and regulate his emotions stably. It is important to reduce anxiety and depression. This theme is also reinforced by Feng et al. (2020; Post, 2008). Post (2008) also adds that when individuals have a high spirit of altruism, they tend to be happier and not feel lonely in their lives. Employees will feel healthier, more passionate, and enthusiastic in their work so that they will be healthier, more prosperous, have a long, and useful life. This is what is recommended in Islam, namely that a person has a purpose in life, namely safety and happiness in this world and the hereafter. Ta awun behavior can serve as Islamic counseling to help employees live happily and stress-free (Hijrati, 2020), safe in this world and the hereafter. This also supports study findings that when employees experience high work stress, their performance will decrease (H3 is accepted). This means supporting Pandey (2020; Ajay, 2018; Mohsan, et al. (2011; Wu, 2011) that companies should be able to reduce 
employee work stress so that their performance increases. The whole explanation above also supports $\mathrm{H} 6$ that work stress can mediate taawun behavior. This study turned out that WLBIP is not able to mediate Ta' awun behavior on employee performance (H7 rejected). This means WLBIP still has a direct effect on employee performance. WLBIP is believed to be able to directly improve performance by focusing on work-life balance and non-work-life balance by continuing to emphasize and familiarize all activities carried out with the intention to obtain the pleasure and reward of Allah SWT so that there is a balance of life in this world and the hereafter.

\section{LIMITATION AND FUTURE RESEARCH}

Research limitations and future research are;

1. The respondents are limited to employees who work in Islamic financial services companies. The sample needs to be expanded by considering employees who work in manufacturing companies so that the results can better represent the research model that considers ta awun behavior, work stress, WLBIP, and employee performance.

2. The model in the future should consider implementing not only Islamic companies that are identical with Islamic culture but can also be applied to non-Sharia companies since this model is very useful for improving employee and company performance.

3. There are several other variables that can be considered in analyzing the impact of ta' awun behavior and there are still many opportunities to be developed by testing and analyzing them, such as organizational commitment, work satisfaction, employee empowerment, (Youssef \& Luthans, 2007; Luthans, 2011), behavioral outcomes, and psychological well-being (Kim et al., 2018).

4. It is necessary to develop concepts and other measures of positive behavior in an Islamic perspective such as; ta' awun (likes to help), as sholeh (good and beneficial), Al Itqan (stable personality), Al Ihsan (doing good), Al mujahadah (hard and optimal work) and tawadhu 'behavior (a person who is not arrogant and humble).

5. Kim et al. (2018) have examined the antecedents and consequences of POB. The results conclude that employees' meaningful work and a supportive organizational climate are predictors of psychological capital so that they can increase work satisfaction and psychological well-being. It means that Psychological capital can be considered as a mediator in future research. 


\section{References}

Ajayi, S. (2018). Effect of Stress on Employee Performance and Work satisfaction: A Case Study of Nigerian Banking Industry, April 11, Labor: Personnel Economics eJournal, Available at SSRN: https://ssrn.com/abstract=3160620 or http://dx.doi.org/10.2139/ssrn.3160620

Aji, A. M. (2015). Hak Dan Kewajiban Asasi Manusia Dalam Perspektif Islam. SALAM: Jurnal Sosial dan Budaya Syar-i, 2(2), 209-228.

Astuti, S.D., Shodikin, A., \& UD-DIN, M. (2020). Islamic Leadership, Islamic Work Culture, and Employee Performance: The Mediating Role of Work Motivation and Work satisfaction. Journal of Asian Finance, Economics and Business, 7(11), 1059-1068.

Bailey, C., Madden, A., Alfes, K., \& Fletcher, L., (2017). The meaning, antecedents and outcomes of employee engagement: A narrative synthesis, International Journal of Management Reviews, 19(1), 31-53.

Balad, N.A. (2019). Prinsip Ta'awun Dalam Konsep Wakaf Dengan Perjanjian Sewa Menyewa Berdasarkan Undang-Undang Nomor 41 Tahun 2004 Tentang Wakaf. Jurnal Hukum Magnum Opus, Februari, 2(1), 18-28.

Cameron, K. S., \& Caza, A. (2004). Contributions to the discipline of positive organizational scholarship. American Behavioral Scientist, 47, 731-739.

Cameron, K., Dutton, J., \& Quinn, R. (Eds.). (2003). Positive organizational scholarship. San Francisco: Berrett- Koehler.

Cavanaugh, M. A., Boswell, W. R., Roehling, M. V., \& Boudreau, J. W. (2000). An empirical examination of self-reported work stress among US managers. Journal of applied Psychology, 85(1), 65-74.

Chen, X., \& Wei, S. (2020). The impact of social media use for communication and social exchange relationship on employee performance. Journal of Knowledge Management, 24(6), 12891314. https://doi.org/10.1108/JKM-04-2019-0167

Csikszentmihalyi, M., \& Seligman, M. E. (2000). Positive psychology: An introduction. American psychologist, 55(1), 5-14.

Drapeau, A., Marchand, A., \& Beaulieu-Prevost, D. (2012). Epidemiology of Psychological Distress.Canada: InTech.

Feng, Y., Zong, M., Yang, Z., Gu, W., Dong, D., \& Qiao, Z. (2020). When altruists cannot help: the influence of altruism on the mental health of university students during the COVID-19 pandemic. Global Health 16, 61. https://doi.org/10.1186/s12992-020-00587-y

Gibson, J.L., Ivanchevich, J.M., \& Donelly, J.H. (1996). Organisasi Perilaku Struktur Proses. Terjemahan. Jilid 1 Edisi Kedelapan, Jakarta : Binarupa Aksara

Hair, J. F., Black, W. C., Babin, B. J., \& Anderson, R. E. (2014). Multivariate Data Analysis, Seventh Edition, Pearson Educational Limited, United States of America.

Hijrati, R. (2020). Konsep Ta'awun Menurutal-Qur'an dan Pengembangannya Dalam Konseling Islam. Tesis, Fakultas Dakwah Dan Komunikasi Universitas Islam Negeri Ar Ranirydarussalam-Banda Aceh1442h/ $2020 \mathrm{M}$

Hill, E. J., Hawkins, A. J., Ferris, M., \& Weitzman, M.(2001). Finding an extra day a week: The positive influence of perceived job flexibility on work and family life balance. Family Relations, 50(1), 49-54.

Irawanto, D. W., Noermiyati, \& Primasari, D. (2015). The Effect of Occupational Stress on Work Performance of Female Employees: Study in Indonesia. Asia-Pacific Journal of Management Research and Innovation, 11(4), 336-345. https://doi.org/10.1177/2319510X15602970 
Isse, H., Abdirahman, H., Najeemdeen, I.S., Abidemi, T., \& Ahmad, R. B. (2018). The Relationship between Work satisfaction, Work-Life Balance and Organizational Commitment on Employee Performance. Academic Journal of Economic Studies, 4(3), 12-17.

Jaharuddin, N.S., \& Zainol, L.N. (2019). The Impact of Work-Life Balance on Job Engagement and Turnover Intention. The South East Asian Journal of Management, 13(1), 106-118.

Kadiyono, H. (2011). Pengaruh Human Capital terhadap Positive Organizational Behavior Pegawai Divisi Marketing di BUMN Bidang Jasa Wilayah Jawa Barat. Indonesian Journal of Applied Sciences, 1(1), 74-83.

Kamil, N.M., \& Ahmad, K. (2014). Development of a Scale for Measuring the Construct of Organizational Citizenship Behaviour from the Islamic Perspective. Malaysian Management Review, 49(1), 55-66.

Kamil, N.M., Mohamed, S., Aahad, M., Osman, G., \& Khaliq, A. (2014). Investigating The Dimensionality Of Organisational Citizenship Behaviour From Islamic Perspective (Ocbip): Empirical Analysis of Business Organisations In Southeast Asia. Asian Academy of Management Journal, 19(1), 17-46.

Kamil, N.M., Mohamed, S., Selladurai, S. \& Khalid, N. (2015). The Impact of Spirituality And Social Responsibility On Organizational Citizenship Behaviour From The Islamic Perspective: Empirical Investigation Of Malaysian Businesses. Malaysian Journal of Communication, 31(1), 59-80.

Karatepe, O. M., Yavas, U., Babakus, E., \& Deitz, G. D. (2018). The effects of organizational and personal resources on stress, engagement, and job outcomes. International Journal of Hospitality Management, 74, 147-161.

Kessler, R. C. (1979). Stress, social status, and psychological distress. Journal of Health and Social Behavior, 20(3), 259-272. https://doi.org/10.2307/2136450

Kessler, R. C., Andrew, G., Colpe, L. J., Hiripi, E., Mroczek, D. K., Normand, S.-L. T., Walters, E. E., \& Zaslavksy, A. M. (2002). Short screening scales to monitor population prevalences and trends in non-specific psychological distress. Psychological Medicine, 32, 959-976.

Kim, M., \& Kim, A.C.H., Newman, J. I., \& Ferris, G.R., \& Perrewé, P. L. (2019). The antecedents and consequences of positive organizational behavior: The role of psychological capital for promoting employee well-being in sport organizations. Sport Management Review, 22(1), 108-125.

Luthans, F. (2002). Positive organizational behavior: Developing and managing psychological strengths. Academy of Management Perspectives, 16(1), 57-72.

Luthans, F. (2006). Perilaku Organisasi. Terjemahan. Edisi 10 , Andi Offset Yogyakarta.

Luthans, F., \& Youssef, C. M. (2007a). Emerging positive organizational behavior. Journal of Management, 33: 321-349.

Luthans, F., \& Youssef, C. M. (2007b). Positive workplaces. In C. R. Snyder \& S. J. Lopez (Eds.), Handbook of positive psychology (2nd ed.). Oxford, UK: Oxford University Press.

Luthans, F., Avolio, B., Avey, J., \& Norman, S. (2007). Psychological capital: Measurement and relationship with performance and satisfaction. Personnel Psychology, 60, 541-572.

Mardiah, N. (2019). Peranan Positive Organization Behavior Dalam Meningkatkan Kinerja Untuk Menghadapi Era Revolusi Industri 4.0. Maqdis: Jurnal Kajian Ekonomi Islam, 4(2), Juli Desember, 215-225.

Marfuatun, M., \& Muafi, M. (2021). Perceived organizational support and psychological empowerment on service performance mediated by organizational citizenship behavior 
Islamic perspective (OCBIP). International Journal of Research in Business and Social Science, 10(1), 15-27.

Matandra, Z., Wahab, A., \& Syaharuddin (2020). The Role of Ta' awun in Alleviating Poverty in Makassar City. Gorontalo Development Review(GOLDER), 3(2), 72-87.

Mohsan, F., Nawaz, M.M., \& Khan, S. (2011). Impact of Stress on Job Performance of Employees Working in Banking Sector of Pakistan. Interdisciplinary Journal of Contemporary Research in Business, 3(2), 1982-1991.

Muafi, M. (2021a). Investigating The Dimensionality Of Work Life Balance In Islamic Perspective (WLBIP): An Insight From Indonesia. Journal of Islamic Business and Management, 11(01), 198-216..

Muafi, M. (2021b). Work Life Balance In Islamic Perspective (WLBIP) questionnaire, Copyright Document, No. 000247018, April 15, Kementerian Hukum dan Hak Asasi Manusia, Republik Indonesia.

Muafi, M., Siswanti, Y., \& Anwar, M.Z. (2021). Work Life Balance in Islamic Perspective: Its Impact on Organizational Citizenship Behavior in Islamic Perspective and Service Performance. International Journal of Research in Business and Social Science 10(3), 223-230.

Najmiah, A. (2021). Implementasi etika bisnis \& pemasaran pada herba penawar al wahida dengan metode AHP (Analitycal Hierarcy Process). Jurnal AKRAB JUARA,6(1), 213-229.

Pandey, D.L. (2020). Work Stress and Employee Performance: An Assessment Of Impact Of Work Stress. International Research Journal of Human Resource and Social Sciences, 7(5), 124-135.

Post, S.G. (2005). Atruism, Happiness, and Health: It's Good to Be Good. International Journal of Behavioral Medicine, 12(2), 66-77.

Prasanty, N. (2014). Hubungan antara stres kerja di lingkungan kerja dengan distres psikologik dan disfungsi sosial pada perawat di RS. Haji Medan. Tesis, Magister Kedokteran Klinik Spesialis Ilmu Kedokteran Jiwa Fakultas Kedokteran, Universitas Sumatera Utara Medan.

Qomaro, G.W., \& Oktasari, A. (2018). Manisfestasi konsep ta'âwun dalam zaakwaarneming perspektif hukum perikata. Et-Tijarie, 5(1),11-25.

Ramlall, S.J. (2008). Enhancing Employee Performance Through Positive Organizational Behavior. Journal of Applied Social Psychology, 38(6), 1580-1600.

Reddy, N.K., Vranda, M., Ahmed, A., Nirmala, B., \& Siddaramu, B. (2010). Work-life balance among married women employees. Indian Journal of Psychological Medicine, 32(2), 112118.

Risaldi, F. (2019). Adaptasi Santri Baru Luar Negeri Di Pondok Modern Darussalam Gontor. SAHAFA Journal of Islamic Communication, 2(1), 49-60.

Rosyidi, A.M. (2015). Hubungan antara budaya kerja dengan sikap ta' awun guru di SMK Muhammadiyah Salatiga tahun pelajaran 2014/2015. Skripsi, IAIN Salatiga

Sani, A. \& Ekowati V.M (2019). Spirituality at Work and Organizational Commitment As Moderating Variables In Relationship Between Islamic Spirituality and OCBIP And Influence Toward Employee Performance. Journal of Islamic Marketing, 11(6), 1777-1799.

Schmitt, A., Ohly, S., \& Kleespies, N. (2015). Time Pressure Promotes Work Engagement. Journal of Personnel Psychology, 14(1), 28-36.

Septiana, N., \& Khairani (2020). Muda, Berani dan Tanpa Pamrih: Karakter Gritpada Perilaku Ta' awun Relawan Muda Muhammadiyah. Jurnal Sains Psikologi, 9(10), 15-25.

Shelly., \& Narang, R. (2000). Effects of Gender and Stress on Altruism. The International Journal of Indian Psychology, 6(2), 139-146. 
Sparrow, E.P., Armstrong, B.A., Fiocco, A.J., \& Spanio, J. (2018). Acute Stress and Altruism in Younger and Older Adults. Psychoneuroendocrinology, https://doi.org/10.1016/j.psyneuen.2018.09.025

Tamunomiebi, M., \& Oyibo, C. (2020). Work-Life Balance and Employee Performance: A Literature Review. European Journal of Business and Management Research, 5(2), 1-10. https://doi.org/10.24018/ejbmr.2020.5.2.196.

Thompson, I. B. (2013). Challenge and hinderance stressor appraisals, personal resources, and work engagement among K-12 teachers. Thesis, University of Tennessee at Chattanooga.

Wasitowati., \& Sudarti, K. (2019). Peningkatan Service Performance Melalui Ta' awun, Religiosity Dan Mood. Fokus Ekonomi, 14(1), 133 -150.

Wu, Y.C. (2011). Job Stress and Job Performance Among Employees in the Taiwanese Finance Sector: The Role of Emotional Intelligence. Social Behaviour and Personality. 39(1), 21-32.

Youssef, C. M., \& Luthans, F. (2007). Positive Organizational Behavior in the Workplace: The Impact of Hope, Optimism, and Resilience. Management Department Faculty Publications, 36. 